\title{
Implementation of Cooperative Learning Model Learning Through The STAD Method in Improving Student's Critical Thinking Ability
}

\author{
Iin Khairunnisa ${ }^{1}$, Muhammad Thariq Aziz ${ }^{2}$ \\ ${ }^{1}$ Economic Education, Sekolah Tinggi Keguruan dan Ilmu Pendidikan PGRI Sukabumi, Indonesia \\ ${ }^{2}$ Information Technology Education, Muhammadiyah Sukabumi University, Indonesia \\ ${ }^{1}$ iinkhairunnisa@stkippgrisukabumi.ac.id, ${ }^{2}$ thariq@ummi.ac.id
}

Keyword:
Cooperative Learning
Model;
Student Critical
Thinking;
Learning STAD Method.

\begin{abstract}
ABSTRAK
This study is about the application of Cooperative Learning models through the STAD method to improving students' critical thinking. The problem in this study was the low critical thinking of students about eleven-class economic subjects in the social studies program at one of the secondary schools in Sukabumi City. The research method used was a quasi experiment with research design The Pre-Equivalent Pre-test - Post Design Control-Test Group. Based on the test for normality, homogenies, and t-test from the pre-test post-test data, the students understood the concept of the experimental class and the control class. The sampling technique used was purposive sampling. Data collection uses tests and assignments. The results of this study were tested with one-way Anava. The results of the study are as follows. 1) Cooperative learning model STAD method is effective for increasing interest and learning outcomes (Critical Thinking) Economic Subjects, 2) STAD learning model in class XI IPS A is more effective in increasing student learning interest compared to STAD method in class XI IPS B, while Method STAD in class XI IPS B is more effective to improve student learning outcomes compared to Class XI IPS A.
\end{abstract}

Article History:

Received: 09-02-2019

Revised : 20-03-2019

Accepted: 28-04-2019

Online : $30-04-2019$

\author{
This is an open access article under theCC-BY-SA license \\ Crossref \\ https://doi.org/10.31764/ijeca.v2i1.2042
}

\section{A. INTRODUCTION}

Education is seen as the right way to form quality human beings to support the achievement of national development goals. Through education, people get knowledge, skills, values and attitudes so they can think more systematically, rationally, and critically about the problems they face. The progress of a nation is largely determined by the nation's educational creativity itself, because education is an effort to print high-quality and dedicated human resources.

The ability needed to be a successful human being is the ability to (a) think critically, analyze and solve complex real-world problems, (b) find, evaluate, and use appropriate learning resources, (c) work together in teams and small groups, (d) effective oral and written communication skills and (e) using content knowledge and intellectual skills to become continuous learners (Sisworo \& Dkk, 2016). Furthermore, stated that some skills that must be possessed in the knowledge era are (a) critical-thinking skills and hard work, (b) creativity, (c) 
collaboration, (d) cross-cultural understanding, (e) communication, (f) computation, and (g) career and independence. As stated by (Aghni, 2018) that current learning seems that students are less encouraged to develop thinking skills, students are directed to memorize information and are forced to remember, and to accumulate a variety of information without being required to understand the information they remember to connect with everyday life.

Experts point out the various notions of critical thinking. Critical thinking is one component in a high-level thinking process, using basic analysis of arguments and insights into each meaning and interpretation to develop cohesive and logical reasoning (Stiawan et al., 2014). That critical-thinking is an active and systemic and reasonable effort, considering various points of view to understand and evaluate an information about the aim of determining whether the information is accepted, rejected or suspended (Nusarastriya et al., 2013). Critical-thinking is the awareness of self-reflection (self-reflection), and ability (basic skills) and willingness (willingness to ask) to clarify and enhance understanding that helps in drawing the right conclusions and making the best decisions in a knowledge-based context (Sugiyanto \& Utami, 2018). Cognitive skills that are at the core of critical-thinking skills include; interpretation (analysis), analysis (analysis), evaluation (evaluation), inference (inference), explanation (explanation), and self-regulation (Facione, 2000).

Students are seen as unique and distinctive individuals from one another who had different abilities such as academic ability and thinking ability. There are students who have high, medium and low abilities (Suharsimi;, 2013). In addition, students can be classified into smart, middle, and stupid categories (Nasution, 2010). The difference in hypothetical ability is very important to be considered in learning (Hadi \& Radiyatul, 2014). The gap between students with upper and lower abilities must be considered and expected that the gap will be minimized both in the process, and the result of learning and combined learning affect the success of student learning (Nugraha et al., 2019), found that academic ability influences students' critical-thinking skills, and the results of research on combine learning strategies influence critical-thinking skills. The learning strategies support the development of critical-thinking skills (Sadia, 2008).

One of the determinants of learning success is determined by the approach, strategy, model, and method or learning techniques used by the teacher. To determine the model or method of learning that is suitable for accounting materials require knowledge and understanding of the teacher both on the material, situation, conditions, and especially the learning model to be used. STAD type Cooperative Learning Model (Student Teams-Achievement Divisions) / Team Achievement Group students).

According to Anita Lie in her book "Cooperative Learning," that the Cooperative Learning model is not the same as just group learning, but there are basic elements that distinguish it from group division, which is done carelessly. Roger and David Johnson said that not all group work can be considered as Cooperative Learning, for that five elements of the mutual learning model must be applied, namely: Positive interdependence, individual responsibility, in person, communication between members, group process evaluation. While the application of this model is supported by the STAD type, where students achieve or understand heterogeneous groups other students so that they are expected to succeed in learning. The STAD type learning strategy has a prominent character, as an illustration. The intensity of collaboration between students in groups is high.

\section{B. METHODS}

In accordance with the type of research design used, the design in this study is The NonEquivalent Pre-test - Post-Test Control Group Design. Where this design there are two groups of experimental groups and control groups. This research is grouped into three stages, namely preparation phase, implementation stage, and reporting stage. The research procedure to be carried out is three stages: 
1. Preparation stage

a. This stage starts from the proposal submission which is then selected by the committee.

b. Develop learning plans, questions and research instruments.

c. Choosing schools and classes that will be used as experimental class and control class

d. Testing instruments outside of the study sample, analyzed and revised.

2. Implementation phase

a. Provides a pre-test of students' critical thinking skills in the experimental class as well as in the control class.

b. Implement learning process STAD type Cooperative Learning in experimental class and ordinary learning (lecture) in control class.

c. Provide post-test of critical thinking instruments of students in the experimental class as well as the control class.

3. Reporting phase

a. Analysis of data processing,

b. Conclusion of research results,

c. Create a research report.

\section{RESULT AND DISCUSSION}

In general, economic learning in class groups goes well. At the first meeting, both in the class with the cooperative learning model STAD type in class XI IPS A and with STAD type cooperative learning in class XI IPS B has not been implemented properly and in accordance with what was planned, because the use of time is less effective by allocating time too long for a certain stage so that it passes through another stage.

In this study there are several data, namely interest and critical thinking skills (learning outcomes). Critical thinking (learning outcomes) obtained from the implementation of the pretest and post-test of economic learning material in the cooperative learning group STAD type conventional learning group. Data on learning interest was obtained from the dissemination of interest instruments at the time of the pre-test and post-test in the learning group. To facilitate the reading of all data in the cooperative learning group STAD type XI IPS A, the IPS B class and conventional learning are recapitulated in the description of the following pre-test and post-test.

\section{a. Class XI IPS A}

The results of the research data in class XI IPS A from learning activities include the percentage of interest and critical thinking (learning outcomes).

1) Interest in learning with the STAD learning model

To facilitate knowing the increased interest in learning, the following is presented a table of student learning interest from the Pre-test and post-test in class XI IPS A below.

Table 1. Interest in learning to class XI IPS A

\begin{tabular}{lllllc}
\hline \multirow{2}{*}{ Category } & \multicolumn{2}{c}{ Pre-test } & \multicolumn{2}{c}{ Post-test } & Enhancement \\
\cline { 2 - 5 } & $\mathrm{F}$ & $\%$ & $\mathrm{~F}$ & $\%$ & $(\%)$ \\
\hline High & 11 & 33,33 & 15 & 45,45 & 12,12 \\
\hline Is being & 22 & 66,67 & 18 & 54,55 & 12,12 \\
\hline Low & 0 & 0 & 0 & 0 & \\
\hline Amount & 33 & 100 & 33 & 100 & \\
\hline
\end{tabular}


Based on Table 1 above learning interest in the class with the STAD cooperative learning model in class XI IPS A has increased with a high category. This is evidenced by the post-test results of $45.45 \%$ while the pre-test results are $33.33 \%$. In other words the STAD type cooperative learning model experienced an increase of $12.12 \%$.

2) Learning Outcomes with the STAD learning model in class XI IPS A

To facilitate knowing the improvement of learning outcomes, the following is presented a table of student learning outcomes from Pre-test and post-test in the class with STAD type cooperative learning in class XI IPS A below.

Table 2. Critical thinking (learning outcomes) in class XI IPS A

$\begin{array}{llclcc}\text { Category } & \text { Pre-test } & \text { F } & \begin{array}{c}\text { Post-test } \\ \%\end{array} & \begin{array}{c}\text { Enhancement } \\ (\%)\end{array} \\ \text { Complete } & \mathrm{F} & \% & \mathrm{~F} & 96,97 & 54,55 \\ \text { Not Complete } & 14 & 42,42 & 32 & 3,53 & 54,55 \\ \text { Amount } & 19 & 57,58 & 1 & 3,03 & \end{array}$

Table 2 above can show that learning outcomes in the experimental group after learning is done from the total number of students $96.97 \%$ reach KKM. This means that learning using the STAD type cooperative model can improve learning outcomes with a change of $54.55 \%$.

\section{b. Class XI IPS B}

The research data on the class using STAD type cooperative learning in the IPS XI B class of learning activities included the percentage of interest and learning outcomes.

1) Critical Thinking Ability with the STAD learning model

To facilitate knowing the increase in interest in learning, the following is presented a table of student learning interest as a result of the Pre-test and post-test in class XI IPS B below.

Table 3. Interest in learning to class XI IPS B

\begin{tabular}{|c|c|c|c|c|c|}
\hline \multirow{2}{*}{ Category } & \multicolumn{2}{|c|}{ Pre-test } & \multicolumn{2}{|c|}{ Post-test } & \multirow{2}{*}{$\begin{array}{c}\text { Enhancement } \\
(\%)\end{array}$} \\
\hline & $\mathrm{F}$ & $\%$ & $\mathrm{~F}$ & $\%$ & \\
\hline High & 12 & 36,36 & 23 & 69,70 & 33,34 \\
\hline Is being & 21 & 63,64 & 10 & 30,30 & 33,34 \\
\hline Low & 0 & 0 & 0 & 0 & \\
\hline Amount & 33 & 100 & 33 & 100 & \\
\hline
\end{tabular}

Based on Table 3 above it can be understood that after STAD type cooperative learning in class XI IPS B studied with a percentage of $69.70 \%$ with a frequency of 23 out of 33 students. In other words, the interest in learning in STAD learning has increased by $33.34 \%$.

2) Learning outcome with the STAD learning model in class XI IPS B

To facilitate knowing the improvement of learning outcomes, the following is presented a table of student learning outcomes from the pre-test and post-test in the XI IPS B class group with the STAD type cooperative learning below.

Table 4. Critical thinking (learning outcomes) in class XI IPS B

\begin{tabular}{cccccc}
\hline \multirow{2}{*}{ Category } & \multicolumn{2}{c}{ Pre-test } & \multicolumn{2}{c}{ Post-test } & \multirow{2}{*}{$\begin{array}{c}\text { Enhancement } \\
\text { (\%) }\end{array}$} \\
\cline { 2 - 5 } Complete & $\mathrm{F}$ & $\%$ & $\mathrm{~F}$ & $\%$ & 60,61 \\
\hline Not Complete & 12 & 36,36 & 32 & 96,97 & 60,61 \\
\hline Total & 21 & 63,64 & 1 & 3,03 & $=$ \\
\hline
\end{tabular}


Based on table.4 above it can be understood that learning outcomes after learning in the class with the STAD type cooperative learning model at XI IPS B reached $96.97 \%$ with a frequency of 32 out of 33 students reaching KKM, so STAD type cooperative learning changed by $60,61 \%$.

\section{c. Class Conventional}

Data on the results of research on the class that uses conventional learning from learning activities include the percentage of interest and learning outcomes.

1) Interest in learning models Conventional

To facilitate knowing the increasing interest in learning, the following is presented a table of student learning interest as a result of the Pre-test and post-test in the Conventional class below.

Table 5. Interest in learning to class Conventional

\begin{tabular}{lccccc}
\hline Category & \multicolumn{2}{c}{ Pre-test } & \multicolumn{2}{c}{ Post-test } & \multirow{2}{*}{$\begin{array}{c}\text { Enhancement } \\
\text { nyyynn}\end{array}$} \\
\cline { 2 - 5 } & $\mathrm{F}$ & $\%$ & $\mathrm{~F}$ & $\%$ & \\
\hline High & 12 & 36,36 & 14 & 42,42 & 6,06 \\
\hline Is being & 21 & 63,64 & 19 & 57,58 & 6,06 \\
\hline Low & 0 & 0 & 0 & 0 & \\
\hline Amount & 33 & 100 & 33 & 100 & \\
\hline
\end{tabular}

To make it easier to read the following learning interests are presented in the form of diagrams. Based on table 5.5 above, it can be understood that after conventional learning as usual in class XI Human High School IT Insani interest in learning with a percentage of $42.42 \%$. In other words the interest in learning in conventional learning has increased by $6.06 \%$.

2) Learning outcome with the STAD learning model in class Conventional

To facilitate knowing the improvement of learning outcomes, the following is presented a table of student learning interest as a result of the Pre-test and post-test in the conventional class below.

Table 6. Critical thinking (learning outcomes) in class Conventional

\begin{tabular}{cccccc}
\hline \multirow{2}{*}{ Category } & \multicolumn{2}{c}{ Pre-test } & \multicolumn{2}{c}{ Post-test } & Enhancement \\
\cline { 2 - 5 } & $\mathrm{F}$ & $\%$ & $\mathrm{~F}$ & $\%$ & $(\%)$ \\
\hline Complete & 12 & 36,36 & 29 & 87,88 & 51,52 \\
\hline Not Complete & 21 & 63,64 & 4 & 12,12 & 51,52 \\
\hline Amount & 33 & 100 & 33 & 100 & \\
\hline
\end{tabular}

Based on Table 6 above shows that the learning outcomes in the class with conventional learning have increased from $36.36 \%$ to $89.88 \%$, meaning that after conventional learning has changed $51.52 \%$.

\section{Hypothesis Testing Results}

Before testing hypotheses 1 and 2, the decision-making methods are determined as follows. If $\mathrm{p}<0.05$, then $\mathrm{HO}$ is rejected, meaning that there is a significant difference between the learning outcomes of students studying with the STAD learning model in class XI IPS A, class XI IPS B and conventional.

\section{a. Hypothesis Testing 1}

The hypothesis tested on this hypothesis is Ho = STAD type cooperative learning model on experimental class XI IPS A class and XI IPS B class does not show differences 
in interests and critical thinking skills (learning outcomes). Hi = STAD type cooperative learning model in class XI IPS A class and XI IPS B class together shows differences in interest and critical thinking skills (learning outcomes). The criteria used in decision making is if the significance value is $<0.05$, then Ho is rejected, conversely if the significance value is $>0.05$ then Ho is accepted.

To test this hypothesis, one-way ANOVA is used with the 16.00 for windows program facility. Based on the calculation, the value of $p=0,000$ means that the significance value is $<0.05$ so that Ho is rejected. Based on these calculations, it can be concluded that the STAD type cooperative learning model in class XI IPS A and Class XI IPS B together shows differences in interest and Critical thinking ability (learning outcomes). STAD type cooperative learning model in class XI IPS A and Class XI IPS B can increase interest and critical thinking (learning outcomes) seen from the results of a summary of the increase in interest and learning outcomes following.

Table 7. Increased Summary of Requests for Classroom Learning

\begin{tabular}{lllll}
\hline Category & \multicolumn{2}{c}{ Class XI IPS A } & \multicolumn{2}{c}{ Class XI IPS B } \\
\cline { 2 - 5 } & \multicolumn{1}{c}{ Pra- Experiment } & Pasca- Experiment & Pra-Experiment & Pasca- Experiment \\
\hline High & $36,36 \%$ & $69,70 \%$ & $33,33 \%$ & $45,45 \%$ \\
\hline Is being & $63,64 \%$ & $30,30 \%$ & $66,67 \%$ & $54,55 \%$ \\
\hline Low & 0 & 0 & 0 & 0 \\
\hline Amount & 100 & 100 & 100 & 100 \\
\hline
\end{tabular}

Based on Table 7 above it can be understood that after Cooperative learning Type STAD PS XI IPS A and XI IPS B interest in learning in both classes experienced an increase in class XI IPS B from before the action was 33.33\% to $45.45 \%$ after the action, while in class XI IPS A from $36.36 \%$ to $69.70 \%$.

Table 8. Summary of improvement in Learning Outcomes

\begin{tabular}{lllll}
\hline \multirow{2}{*}{ Category } & \multicolumn{2}{c}{ Class XI IPS A } & \multicolumn{2}{c}{ Class IPS B } \\
\cline { 2 - 5 } & Pre-test & Post-test & Pre-test & Post-test \\
\hline Complete & $36,36 \%$ & $96,97 \%$ & $42,42 \%$ & $96,97 \%$ \\
\hline Not Complete & $63,64 \%$ & $03,03 \%$ & $57,58 \%$ & $03,03 \%$ \\
\hline Amount & 100 & 100 & 100 & 100 \\
\hline
\end{tabular}

Based on Table 8 above, it can be understood that after the PS and Jigsaw learning in class XI IPS A and XI OPS B the learning outcomes in both classes experienced an increase in class XI IPS A from $36.36 \%$ to $96.97 \%$, while in class XI IPS B from $42.42 \%$ to $96.97 \%$.

Based on the results of hypothesis testing which concluded that there were significant differences between groups of classes, it means that it is necessary to do post hoc to analyze hierarchical effectiveness between learning models. Therefore, further testing used LSD analysis in detail comparing between class groups. Based on data from research results processed using SPSS version 16 . The results of the analysis showed that Ho was rejected, because all classes were compared to obtain $p<0.05$, meaning that there were significant differences between the three classes.

\section{b. Hypothesis Testing 2}

Based on the results of hypothesis 1 test above which concludes that there is a significant difference between the STAD learning model in class XI IPS A and class XI IPS B and conventional, it means that it is necessary to post hoc to analyze the hierarchy of effectiveness between STAD Class XI IPS A and Class type learning models. XI IPS B and conventional. Which of the three classes is the most effective in improving 
learning outcomes. therefore further testing uses the LSD test analysis in detail comparing between classes.

Experimental findings on learning outcomes can be discussed further seen from the average value that STAD type cooperative learning in class XI IPS B is more effective than STAD type cooperative learning in class XI IPS A, STAD type cooperative learning in class XI IPS A is more effective than with conventional learning in class XI Human High School IT. In other words, it can be formulated in a hierarchical learning model that has the highest average value in improving learning outcomes by STAD type cooperative learning in class XI IPS B then with STAD type cooperative learning in class XI IPS A then conventional learning in Human High School IT Insani class.

Table 9. ANOVA Test Results One Path of Learning Interest in the Entire Class.

\begin{tabular}{llllll}
\hline ANOVA & \multicolumn{5}{l}{} \\
\hline Learning interests & \multicolumn{7}{l}{} \\
\hline & Sum of Squares & df & Mean Square & F & Sig. \\
\hline Between Groups & 146.505 & 2 & 73.253 & 3.328 & .040 \\
\hline Within Groups & 2113.152 & 96 & 22.012 & & \\
\hline Amount & 2259.657 & 98 & & & \\
\hline
\end{tabular}

Based on Table 9 displays the results of the overall average difference test. In the table found the F value of 3.328 with sig $=0.040$. Because the value of sig $<0.05$, Ho is rejected so that it can be concluded that there are differences in the average interest in learning in learning using Conventional, Jigsaw and PS. (If the test results are significant then proceed to the post hoc test, but if not significant the test stops here).

Significant value between class XI IPS (konv SMA Insani) with class XI IPS B (Nurul Karomah) was 0.875 and greater than 0.05 . this means that the average learning interest of the XI IPS class (konv SMA Insani) is the same as the average interest in learning in class XI IPS B (Nurul Karomah). The table above also shows XI IPS (conventional SMA Insani) with class XI IPS A (Nurul Karomah) of 0.034 and less than 0.05. This means that the average learning interest of class XI IPS A (Nurul Karomah) is better than class XI IPS (conv SMA Insani). The table above also shows that the significance value of class XI IPS A (Nurul Karomah) with class XI IPS B (Nurul Karomah) is 0.23 and less than 0.05 . This means that the average learning interest of class XI IPS B (Nurul Karomah) is better than class XI IPS A (Nurul Karomah). Based on the results of the test it can be concluded that the highest average learning interest is achieved by the STAD learning model, while the conventional learning model has the lowest average learning interest.

Table 10. ANOVA Test Results for One Learning Outcomes in the Entire Class.

\begin{tabular}{llllll}
\hline ANOVA & \multicolumn{5}{l}{} \\
\hline Learning Outcomes & \multicolumn{7}{l}{} & & & \\
\hline & Sum of Squares & df & Mean Square & F & Sig. \\
\hline Between Groups & 204.788 & 2 & 102.394 & 10.376 & .000 \\
\hline Within Groups & 947.394 & 96 & 9.869 & & \\
\hline Amount & 1152.182 & 98 & & & \\
\hline
\end{tabular}

In Table 10 displays the results of the overall average test difference. In the table found the $F$ value of 10.376 with sig $=0,000$. Because the value of sig $<0.05$, Ho is rejected so that it can be concluded that there are differences in the average learning outcomes in learning using Conventional, Jigsaw and PS. (If the test results are significant then proceed to the post hoc test, but if not significant the test stops here). 
Significant value between class XI IPS (konv SMA Insani) with class XI IPS B (Nurul Karomah) is 0,000 and less than 0.05 . this means that the average learning outcomes of class XI IPS B (Nurul Karomah) are better with the average learning outcomes of class XI IPS (konv SMA Insani). The table above also shows a significant value between class XI IPS (konv SMA Insani). with class XI IPS A (Nurul Karomah) of 0,000 and less than 0.05. This means that the average learning interest of class XI IPS A (Nurul Karomah) is better than class XI IPS (konv SMA Insani). The table above also shows that the significance value of class XI IPS A (Nurul Karomah) with class XI IPS B (Nurul Karomah) is 0.784 and greater than 0.05 . This means that the average interest in learning class XI IPS A (Nurul Karomah) is the same as the average learning rate of class XI IPS B (Nurul Karomah). Based on the results of the test it can be concluded that the highest average learning outcomes are achieved by the STAD type cooperative learning model, while the conventional learning model has the lowest average learning interest.

\section{Discussion}

After the researchers conducted research and experiments in the field, explained several findings, performed data processing and analysis, then the researchers discussed the results of their research. In the end making conclusions, conclusions are a summary of the answers to the research questions described in the previous chapter. The conclusion of this study is that there are differences in critical thinking skills in the learning economy of the experimental class using the Cooperative Learning Model type Student Teams Achievement (STAD) at the initial measurement (pre-test) and at the final measurement (post-test). Differences can be seen in the average value of students' critical thinking skills between before and after treatment in the experimental class which is seen in the value of the pre-test and post-test produced by students and proven by hypothesis testing. With the level of success of students in mastering the material materials of the Economy with a good or maximum.

The critical thinking ability of experimental class students based on pre-test-post-test data analysis shows that there are differences in students' critical thinking skills between before and after treatment using Cooperative Learning models through the STAD method by giving conclusions to increase. The results of this study are in accordance with those conducted by other researchers such as Junaidi (2009) who implemented student team achievement divisions (STAD), as one of the effective cooperative learning methods to increase student grades, Erma Wulandari (2012) who implemented the STAD-type Cooperative Learning Model Media Monopoly increases accounting learning activities of Vocational students, Imas Masturoh (2010) who apply STAD Cooperative Learning models can improve students' rational thinking skills, M Taufik (2009) and Rauzah (2010) who apply STAD Cooperative Learning models to mastering economic concepts. The above research supports and strengthens the research conducted by researchers using Cooperative Learning models through the STAD method can improve students' critical thinking skills in economic learning.

In general this research supports and strengthens Vygotsky's constructivist theory. According to Vygotsky, students have two levels of potential development. Actual Development Level (level of actual development) defines the level of individual intellectual development at this time and the ability to learn special things or individual efforts themselves. Individuals also have a potential level of development (level of potential development) which is defined as the level of intellectual development that can be achieved by individuals with the help of other people such as teachers, parents, or more mature friends. The zone between the actual level of development and the level of potential student development by Vygotsky (2006: 23) is called the Zone of Proximal Development, where learning occurs through social interaction between students and teachers and peers. With challenges and appropriate assistance from the teacher or peers who are better able 
students move forward into the closest development zone where the new learning takes place.

The ability to think critically increases with the medium category, this increase in thinking as an influence from the use of Cooperative Learning models through the STAD method used in the experimental class. The increase in critical thinking skills in the experimental class is caused by the STAD learning method in students occupying a very dominant position, the occurrence of cooperation, mutual assistance, and individual responsibility in groups, where in each learning group is placed one student who has more economic learning skills so that each individual / student in the group tries to understand what is being taught and is responsible for their members. In addition, in the cooperative learning model the STAD method for each teacher uses the question and answer method, practice method and assignment, and even uses the quiz method by how each student will answer by applause where if answered correctly adds individual and group points to reach the best group criteria, so in the accounting learning process students will not be easily bored and bored, even students become interested in economics subject matter because the learning that is done in addition to being relevant to the learning objectives is also fun, in other words learning by using the model will increase student learning motivation.

Based on the results of the implementation of PBM, and observation, it can be concluded that the Cooperative Learning model of the STAD method can influence the improvement of students' critical thinking skills with a moderate category increase. Because this learning model in addition to group learning is also placed in groups of high achieving students with elements of positive interdependence, individual responsibility in groups, exchanging opinions, guiding each other if there are friends in their group who experience difficulties. This is in accordance with the elements contained in Cooperative Learning Models (Munawaroh, 2016), namely positive interdependence, individual responsibility, personal interaction, collaboration skills, and group processes. So that it can improve students' abilities in translation, interpretation, and extraporation. To support these capabilities, educators must be able to integrate learning models with subject matter where the ability to manage a good learning model can deliver the material delivered so that students have the ability to have high translation, interpretation, and extraporation especially with basic competencies in understanding national income.

\section{CONCLUSION AND ADVICE}

After the researchers conducted research and experiments in the field, explained several findings, performed data processing and analysis, then the researchers discussed the results of their research. In the end making conclusions, conclusions are a summary of the answers to the research questions described in the previous chapter. The conclusion of this study is that there are differences in critical thinking skills in the economics of experimental class students who use the Cooperative Learning Model type Student Teams Achievement Division (STAD) at the initial measurement (pre-test) and at the final measurement (post-test). Differences can be seen in the average value of students' critical thinking skills between before and after treatment in the experimental class which is seen in the value of the pre-test and post-test produced by students and proven by hypothesis testing. With the level of success of students in mastering the material material of the Economy with a good or maximum.

Teachers must understand the stages of the Cooperative Learning Model STAD method correctly in the learning process in order to further enhance critical thinking skills in students' economic subjects. The learning process by using the Cooperative Learning Model STAD method requires a lot of time and the teacher must pay attention to the Learning Implementation Plan so that learning takes place efficiently and effectively to achieve predetermined learning goals. Other researchers who use the Cooperative Learning Model STAD method in conducting their 
research must pay attention to other aspects such as affective aspects and psychomotor aspects so that the results of the study are better and perfect. The results of this study cannot be generalized / do not apply to all subjects, all cognitive aspects, all levels of schools, and educators, because of differences in objects and research time.

\section{ACKNOWLEDGEMENT}

Thank you to the beloved alma mater STKIP PGRI Sukabumi who has given the facility and its support to complete this research.

\section{REFERENCES}

Aghni, rizqi alyasa. (2018). menurut wina sanjaya. Fungsi Dan Jenis Media Pembelajaran Dalam Pembelajaran Akutansi,

$x v i$. https://journal.uny.ac.id/index.php/jpakun/article/download/20173/10899

Facione, P. A. (2000). The Disposition Toward Critical Thinking: Its Character, Measurement, and Relationship to Critical Thinking Skill. Informal Logic, 20(1). https://doi.org/10.22329/il.v20i1.2254

Hadi, S., \& Radiyatul, R. (2014). Metode Pemecahan Masalah Menurut Polya untuk Mengembangkan Kemampuan Siswa dalam Pemecahan Masalah Matematis di Sekolah Menengah Pertama. EDU-MAT: Jurnal Pendidikan Matematika, 2(1). https://doi.org/10.20527/edumat.v2i1.603

Munawaroh, S. (2016). Model Pembelajaran Kooperatif ( Cooperative Learning) Dalam Strategi Belajar Mengajar Bahasa. Prosiding Konferensi Nasional Bahasa, 100-116.

Nasution, M. N. (2010). Manajemen Mutu Terpadu (Total Quality Manajement). Jakarta: Ghalia. Manajemen Mutu Terpadu (Total Quality Manajement). Jakarta: Ghalia.

Nugraha, J., MS, Z., \& Fuad, N. (2019). Peningkatan Keterampilan Menulis Deskripsi Melalui Pendekatan Saintifik Dengan Metode Problem Based Learning Di Kelas Iv Sekolah Dasar. Prosiding Seminar Nasional Pendidikan KALUNI, 2. https://doi.org/10.30998/prokaluni.v2i0.37

Nusarastriya, Y. H., H, H. S., Wahab, A. A., \& Budimansyah, H. D. (2013). Pengembangan Berpikir Kritis Dalam Pembelajaran Pendidikan Kewarganegaraan Menggunakan Project Citizen. Jurnal Cakrawala Pendidikan, 3(3). https://doi.org/10.21831/cp.v3i3.1631

Sadia, I. W. (2008). Model Pembelajaran yang Efektif untuk Meningkatkan Keterampilan Berfikir Kritis(Suatu Persepsi Guru). Jurnal Pendidikan Dan Pengajaran UNDIKSHA. https://doi.org/ISSN 02158250

Sisworo, \& Dkk. (2016). Analisis Kemampuan Berpikir Kritis. Prosiding Konferensi Nasional Penelitian Matematika Dan Pembelajarannya, 3(Knpmp I), 580-590. https://doi.org/10.23971/eds.v5i2.732

Stiawan, E., Liliasari, L., \& Rohman, I. (2014). Pengembangan Keterampilan Berpikir Kritis Siswa Sma Pada Topik Teori Domain Elektron Melalui Simulasi Interaktif Phet Molecule Shapes. Jurnal Pengajaran Matematika Dan Ilmu Pengetahuan Alam, 19(2), 257. https://doi.org/10.18269/jpmipa.v19i2.468

Sugiyanto, R., \& Utami, A. (2018). Peningkatan Kemampuan Berpikir Kritis Siswa Dengan Model Tasc (Thinking Actively In A Social Context) Pada Pembelajaran Ips Di Sekolah Dasar. JIPSINDO, 5(2). https://doi.org/10.21831/jipsindo.v5i2.22084

Suharsimi;, A. (2013). Dasar-Dasar Evaluasi Pendidikan. In Jakarta: Bumi Aksara (p. 168). 